\title{
Visuaalisen antropologian perusteos
}

\author{
Kupiainen, Jari ja Liisa Häkkinen (toim.). 2017. Kuvatut kulttuurit: Johdatus \\ visuaaliseen antropologiaan. Helsinki: SKS. 312 sivua.
}

\section{Sinikka Vakimo}

$\mathrm{V}$ isuaalisesta antropologiasta on suomeksi kirjoitettu suhteellisen vähän visuaalisen kulttuurin tutkimuksen painopisteen ollessa pitkälti mediakulttuurissa tai taiteentutkimuksessa. Lisäksi visuaalisia menetelmiä tutkimuksissaan toteuttaneita antropologeja on maassamme ollut niukalti. Toki antropologit, kuten muutkin kulttuurin ja perinteen tutkijat, ovat käyttäneet valokuvia, piirtämistä tai muita visuaalisia apukeinoja esimerkiksi haastatteluaineistoa kootessaan, mutta tutkimuksen päämetodina visuaaliset menetelmät ovat jääneet muiden menetelmällisten otteiden katveeseen.

Jari Kupiaisen ja Liisa Häkkisen toimittamalla teoksella Kuvatut kulttuurit (2017) on siis selvästi tarvetta muun muassa yliopistollisessa menetelmäopetuksessa. Teoksen johdannon mukaan kirja sai alkunsa Suomen Antropologisen Seuran toiveesta. Sen kotimaisena edeltäjänä voi nähdä Anja Tuomiston ja Heli Uuskylän vuonna 1995 toimittaman Kuva, teksti ja kulttuurinen näkeminen -artikkelikokoelman, jossa keskityttiin pääosin valokuvauksen ja valokuvan antiin perinteen ja kulttuurin tutkimuksessa. Myös Stig Söderholmin vuonna 1990 ilmestynyttä antropologian alan väitöskirjaa Liskokuninkaan mytologia voi pitää yhtenä visuaalisen metodiikan tienraivaajana Suomessa sen hyödyntäessä pääaineistonaan valokuvia, videoita ja filmidokumentteja. Näihin kahteen teokseen käsillä olevassa teoksessa ei kuitenkaan viitata eikä niitä lainkaan mainita kirjan sivuilla. Tämä saanee perustelunsa siitä, että molemmissa mainituissa teoksissa pääpaino on valokuvissa, kun taas Kuvatut kulttuurit keskittyy pääosiltaan antropologisen ja etnografisen dokumentaarisen elokuvan kansainväliseen tutkimuskeskusteluun eikä teos edes pyri esittämään visuaalisen metodiikan laajempaa oppihistoriallista katsausta Suomen perspektiivistä.

Visuaalinen antropologia ja antropologinen elokuva on myös useimmissa akateemisissa yksiköissä marginaalisessa asemassa, jos sitä esiintyy lainkaan; Euroopassakin antropologista elokuvaa voi opiskella pääaineenomaisesti vain joissakin yliopistoissa. Lisäksi Suomessa on antropologisen tai etnografisen elokuvan tekeminen jäänyt niukasti harrastetuksi sitten varhaisen kansatieteellisen elokuvatuotannon huippukauden. Tutkija- ja elokuvantekijäpiirit ovat siis varsin pienet niin Suomessa kuin maailmallakin. Myös alan klassikkoelokuvista ollaan ilmeisen yksimielisiä, sillä lähes jokaisessa teoksen antropologista elokuvaa käsittelevässä artikkelissa mainitaan suurin piirtein samat antropologiset elokuvat ja elokuvateoreetikot. 
Kuvatut kulttuurit on jaettu kolmeen temaattiseen "näkymään": teoriaan, historiaan ja menetelmiin. Näistä ensimmäisessä fokusoidutaan neljän artikkelin voimin visuaalisen antropologian nykykeskusteluihin, keskeisiin käsitteisiin sekä erilaisiin rajanvetoihin eri elokuvagenrejen ja tutkimuskenttien välillä. Kirjan toisessa osiossa käsitellään suomalaisen valokuvan ja antropologisen dokumentaarielokuvan historiallisia kehityskaaria, ja kolmannessa esitetään läpivalaisuja useampaan visuaalista metodiikkaa soveltavaan ja sitä problematisoivaan tapaustutkimukseen. Kolmas osio jakaantuu muodoltaan kahtaalle: sen alussa on perinteisiä tutkimusartikkeleita ja loppuosassa keskustelujakso, joka koostuu keskustelutiivistelmästä ja keskusteluun johdattaneesta artikkelista. Kirjasta kokonaiskuvaa sisällysluettelon perusteella hahmotellessani tuntui kirjan kolmannen osion täyttäminen erityyppisillä teksteillä hieman sekavalta; teoksen rakennetta olisi kyllä selkeyttänyt keskustelutiivistelmän ja sitä pohjustavien tekstien erottaminen menetelmällisistä tutkimusartikkeleista. Kirjan luettuani ymmärrän toisaalta toimittajien valinnan, onhan koko kolmannen osion teema - menetelmäkeskustelu - referoidussa keskustelussa näkyvässä roolissa.

Kirjassa on mukana yhteensä yksitoista varsinaista tutkimusartikkelia edellä mainittujen keskusteluun liittyvien tekstien ja kirjan keskeistematiikkaa esittelevän johdantoartikkelin lisäksi. Teoksessa ei valitettavasti ole kirjoittajaesittelyä, mutta ymmärtääkseni teokseen artikkeleita kirjoittaneista suomalaisista kirjoittajista lähes jokainen on joko soveltanut visuaalisen antropologian metodeja tutkimuksessaan tai tehnyt itse joko antropologisia tai dokumentaarisia elokuvia. Antropologisen elokuvatutkimuksen erilaiset toisiinsa risteävät määrittelytraditiot ovat teoksessa hyvin esillä: keskustelua siitä, miten antropologista, etnografista, dokumentaarista tai taide-elokuvaa tulisi rajata, määritellä ja kenties erotella toisistaan, käydään useammassakin artikkelissa ja teoksen lopun keskusteluosassa. Antropologinen elokuva sijoittuukin niin eri alojen tieteellisen keskustelun kuin taiteenkin kentille - ja näiden rajamaille - kiinnostavalla tavalla, minkä lisäksi visuaaliset menetelmät ovat hyödynnettävissä hedelmällisesti lukuisilla tieteenaloilla ja tutkimussuuntauksissa. Kuvatut kulttuurit siis liikkuu varsin keskeisillä kulttuurintutkimuksen alueilla ja aihepiireissä.

\section{Katse teoriaan, käsitteisiin ja niiden liukumiin}

Ensimmäisen osion aloittaa kirjan toisen toimittajan, Jari Kupiaisen katsauksenomainen artikkeli visuaalisen antropologian 2010-luvun keskeisistä käsitteistä ja lähestymistavoista. Kupiaisen mukaan visuaalinen antropologia ymmärretään usein turhan kapea-alaisesti vain antropologisten tai etnografisten elokuvien tekemisenä, vaikka sen tutkimusmenetelmillä on paljon annettavaa erilaisissa kulttuurintutkimuksellisissa suuntauksissa. Kirjoituksessa avataan keskustelua antropologisen ja etnografisen elokuvan määrittelystä ja niiden välisestä rajanvedosta, laajennetaan perspektiiviä kuvallisen ilmauksen käyttöön antropologian tutkimushistoriassa ja myös moniaistisen ja audiovisuaalisen, teknologisoituneen mediakulttuurin tutkimuksessa. Kirjoituksen loppuosassa siirrytään käsitteellisestä ja menetelmällisestä keskustelusta antropologista etiikkaa sivuaviin teemoihin. Tässä yhteydessä Kupiainen pohtii muun muassa representaatioiden politiikkaa ja tutkittavien kulttuuristen ryhmien roolin muutosta koloniaalisen katseen kohteesta mediatoimijoiksi ja audiovisuaalisen itsemääräämisoikeuden haltijoiksi. Kupiaisen kirjoitus toimii hyvin johdantona koko kirjan keskeistematiikkaan ja sen artikkeleihin.

Kupiaisen artikkelia seuraa hiljattain edesmenneen antropologin ja elokuvantekijän Ilkka Ruohosen (1958-2016) postuumisti julkaistu tekijälähtöinen tarkastelu antropologisesta ja 
etnografisesta elokuvasta osana tieteellistä diskurssia ja suhteessa taiteelliseen dokumentaariin. Ruohonen nojautuu tarkastelussaan akateemisen antropologin ja antropologisen elokuvantekijän kokemuksiin ja näkemyksiin ja keskustelee niin antropologisen kuin taide-elokuvankin kentillä erilaisia vastakkainasetteluita kyseenalaistaen. Ruohoselle tuttuun tapaan hänen tekstinsä, kuten hänen elokuvansakin, ovat monitulkintaisuudessaan lukijalle ja katsojalle haasteellisia, mutta palkitsevat niihin perehtyvän monenlaisilla oivalluksilla. Ruohosen artikkeli niveltyy hyvin sitä seuraavaan Jouko Aaltosen tarkasteluun dokumenttielokuvan ja antropologian rajapinnoista. Aaltosen kirjoitus on ihailtavan selkeä, vaikka siinä sekä nostetaan esiin monia eri teoreettisia suuntauksia ja käsitteitä että peilataan taiteen ja tieteen rajapintoja ja valaistaan siten dokumentaarisen ja antropologisen elokuvan tekemistä ja niiden teoretisointia. Aaltonen myös löytää paljon yhtymäkohtia antropologian ja dokumenttielokuvan tekemisen välille: kumpikin edellyttää kykyä ottaa etäisyyttä ja toisaalta identifioitua kuvattavaan kohteeseen ja kummassakin on viime kädessä kyse kulttuurisesta kohtaamisesta. Aaltosen mukaan suomalaiset dokumentaristit sijoittavat itsensä mieluummin taiteen kuin tieteen kentälle, vaikka alat ovat hyvin lähellä toisiaan dokumentaarisen elokuvan edellyttäessä taitoa kertoa asioita omasta kokemuksesta siinä missä taidekin. Kirjan ensimmäisen osion päättää sen toisen toimittajan, Liisa Häkkisen pohdinta visuaalisesta kulttuurintutkimuksesta yhteiskuntatieteissä.

\section{Katse historiaan: etnografinen elokuva ja valokuvat}

Teoksen toisessa temaattisessa osiossa katsastetaan visuaalisen antropologian kysymyksiä historian näkökulmasta ja Suomeen painottuen. Osion aloittaa Mirja Metsolan ansiokas suomalaisen etnografisen elokuvan ja visuaalisen antropologian tarkastelu niiden alkujuurilta lähtien. Metsolan käsitteistössä etnografinen elokuva on laaja kattokäsite, jonka alle mahtuu niin antropologinen tutkimuselokuva kuin yleisölle suunnatut kulttuurista kertovat elokuvalliset tarinatkin, joiksi hän nimeää muun muassa televisio-ohjelmat, sarjat ja draamadokumentit sekä myös perinteiset ja kokeelliset filmit. Etnografisen elokuvan alkuvaiheen Metsola paikantaa joko kansallisiin tai koloniaalisiin, kansojen ja kansanryhmien hallittavuutta korostaviin pyrkimyksiin. Artikkeli lähtee liikkeelle 1900-luvun alun kansanelämän ja "kalevalaisen" elämäntavan kuvauksista siirtyen Sakari Pälsin tutkimusmatkojen filmatisointeihin, 1930-luvun kaitafilmeihin ja nousevaan filmialan yritystoimintaan ja etenee siitä 1940-luvun isänmaallisen kansatieteellisen elokuvan tarkasteluun. Sodanjälkeisen kauden erittely on ymmärrettävästi hajanaisempaa, mikä kuvastaa jälleenrakennusajan, modernisoituvan ja teknologisoituvan Suomen elokuvatuotannon ja sen tarpeiden murroksia. Varsinaisen visuaalisen antropologian tutkimuksellisen lähestymistavan, visuaalisten kenttätyömetodien ja antropologisen elokuvan Metsola näkee rantautuneen Suomeen lähinnä 1960-luvulta alkaen, kun videointilaitteisto alkoi tulla kenttätutkijoiden käyttöön ja myös yliopistoissa käynnistettiin erilaisia hankkeita ja kenttäkursseja, joilla visuaalisia menetelmiä alettiin opettaa. Antropologisen elokuvan alkuvaiheen Metsola kytkee 1970-luvun lopulle ja Heimo Lappalaisen hahmoon, mistä hän vetää joitakin kehityslinjoja 2000-luvulle. Metsolan laaja-alainen, elokuva-alan ammattilaisen ja tutkijan sujuvalla kädellä laadittu artikkeli on kaikin puolin kiintoisaa luettavaa.

Erityisen hienoa on huomata, ettei tv-elokuvatuotantoa ole jätetty Metsolan artikkelissa huomiotta. Toki tarkastelu on tilanpuutteesta johtuen hieman luettelomaista, mutta siinä nousee esiin komea kavalkadi etnografisen elokuvan lähihistoriaa maassamme. Niinpä mainituksi tulevat lukuisat elokuvantekijät ja heidän kanssaan yhteistyötä tehneet (kenttä) 
tutkijat, kuten Lennart Meri, Kustaa Vilkuna, Matti Sarmela, Juha Pentikäinen, Anna-Leena Siikala, Jorma Molarius ja Mirja Metsola. Olisi ollut kiehtovaa nähdä, mihin kehykseen tai jatkumoon Metsola sijoittaisi llkka Ruohosen työn ja antropologiset elokuvat, mutta niihin ei kirjoituksessa viitata. Metsolan historiaan suuntaavaa tarkastelua jatkaa Sirkku Dölle hänen pohtiessaan suomalaisen visuaalisen antropologian juuria ja kehityslinjoja valokuvan suunnasta. Osion päättää Mervi Löfgrenin analyysi sukupuolen esittämisestä 1910-1920-luvuilta peräisin olevissa albumikuvissa ja historiallisen visuaalisen aineiston tulkinnan ongelmista laajemminkin.

\section{Katse visuaalisiin menetelmiin}

Kuvatut kulttuurit -teoksen kolmas osa on teoksen laajin osio, ja siinä esitetään kiehtovasti eri suuntiin kurkottavia tutkimusartikkeleita visuaalisen metodiikan sovelluksista. Osion alussa Jari Kupiainen luotaa valokuvien käyttöä osana antropologisen, kenttätutkimukseen perustuvan tiedon tuotantoa. Kupiainen kontekstualisoi kenttää monikulttuurisuuden, alkuperäisväestöjen ja moninaisten etnisten ryhmien välisten jännitteiden sekä myös antropologi-tutkijan merkityksenannon suunnasta. Kirjoituksessa valokuvien kollaboratiivinen käyttö, kuvien katselu ja tulkinta yhdessä problematisoituu tekstissä monisyisesti. Elina Pajun artikkelissa taas paneudutaan suomalaisessa päiväkodissa tehdyn kenttätutkimuksen metodiikan eettis-refleksiiviseen pohdintaan ja kameran käytön haasteisiin ja etuihin lasten parissa tehdyssä kenttätutkimuksessa. Videokuvan sukupolvittelua tutkimusmenetelmänä tarkastelevat Lea ja Pekka Kantonen yhteisartikkelissaan. Heidän tutkimuksensa muodostaa tapaustutkimuksen, jonka kohteena on Viron Setumaalta kotoisin olevasta Helbi-kuorosta tehdyt videoinnit ja niiden kollektiivinen, dialogisen estetiikan pyrkimyksiin nojautuva kriittinen katselu-, keskustelu- ja väittelyprosessi, jossa on määritelty videotallenteiden muuntuvia merkityksiä. Valtarakenteiden avaaminen ja koloniaalisen katseen purkamisen pyrkimys on siivittänyt tutkimuksen etenemistä. Menetelmäosion viimeisestä varsinaisesta tutkimusartikkelista vastaa Asko Lehmuskallio. Hän fokusoi kirjoituksensa kuvan katsomiseen ja kuvien rooleihin osana inhimillistä toimintaa ja suuntaa berliiniläisten kuva-aktivistien kuvien käytön konventioihin ja tulkintoihin. Tutkimus nojautuu teoreettiseen keskusteluun, jossa on tarkasteltu katseen merkityksellistämisprosesseja ja kuvallisten järjestysten rajojen rikkomista. Kaikki osion artikkelit ovat inspiroivia avauksia omaan suuntaansa, ja ne houkuttelevat lukijaa etsimään lisää tietoa sovelletusta metodiikasta ja sen haasteista.

Kolmannen osion ja koko Kuvatut kulttuurit -teoksen päättävä keskusteluosuus paikantuu Joensuussa edelleenkin järjestettävän kansainvälisen etnografisen dokumenttielokuvafestivaalin, Viscultin 10-vuotisjuhlaan vuonna 2010. Tuolloin paikalle oli saapunut varsin nimekäs joukko antropologisen elokuvan tekijöitä ja tutkijoita, joiden käymä paneelikeskustelu on toimitettu ja suomennettu teokseen. Keskusteluun johdatteli kirjassakin julkaistu ja siihen käännetty Evgeny Aleksandrovin alustus antropologisen elokuvan etiikasta ja estetiikasta niin sanotun "tasapainotetun kameran" (engl. consonant camera) teoretisoinnin muodossa. Keskustelussa tutkija-elokuvantekijät esittivät näkemyksiään visuaalisen antropologian silloisesta tilasta ja sen näkymistä tulevaisuudessa sivuten Aleksandrovin artikkelia vain viitteellisesti. Visuaalisen antropologian metodiseen keskusteluun vihkiytyneelle keskustelutiivistelmä antaa kenties enemmän, mutta itselleni se lähinnä osoitti, että alan tutkijoiden näkemykset voivat olla hyvinkin erilaisia, mikä tarkoittanee alan olevan jatkuvassa liikkeessä globaalisti modernisoituvassa ja yhä laajempia ekologisia ja eettis-moraalisia vaateita asettavassa maailmassa. 
Kuvatut kulttuurit tarjoaa tutkimuksellisia avauksia visuaalisen antropologian teoreettisiin keskusteluihin ja visuaalisen metodiikan sovellusmahdollisuuksiin sekä alan juuriin ja kehityslinjoihin maassamme. Paikoin tekstit ovat aiempaan teoreettiseen keskusteluun vihkiytymättömälle kohtuullisen haastavia haltuunotettavia, ja ne olisivat kenties hyötyneet hieman tarkemmasta johdattelusta. Tekstien lievä epätasaisuus on kuitenkin tyypillistä artikkelikokoelmalle ja toisaalta myös sen rikkaus, kun jokainen kirjoittaja on saanut koostaa tekstinsä itselleen sopivimmalla tavalla. Tämä mahdollistaa myös sen, että kirjasta löytyy varmasti jokaiselle visuaalisista menetelmistä kiinnostuneelle jotain ammennettavaa. Kokonaisuutena teos onnistuu tuottamaan moninaisen käsityksen visuaalisen antropologian tarjoamista mahdollisuuksista antropologian ohella myös kulttuurintutkimuksen kentillä laajemminkin.

\section{Kirjallisuus}

Söderholm, Stig. 1990. Liskokuninkaan mytologia: Rituaali ja rocksankarin kuolema: Jim Morrison-kultin etnografinen tulkinta. Helsinki: Suomalaisen Kirjallisuuden Seura.

Tuomisto, Anja ja Heli Uuskylä. 1995. Kuva, teksti ja kulttuurinen näkeminen. Helsinki: Suomalaisen Kirjallisuuden Seura.

Dosentti Sinikka Vakimo toimii perinteentutkimuksen yliopistonlehtorina Itä-Suomen yliopistossa. 